\title{
Philosophical Aspects of the Legal Content of Regional Regulation in Regional Autonomy
}

\author{
Djumahari Jahidin \\ \{tanahmaleah@gmail.com \}
}

Universitas 17 Agustus 1945 Jakarta, Jakarta, Indonesia

\begin{abstract}
There are three aspects that must be considered in creating laws and regulations, especially regional regulation, namely the philosophical, juridical, and sociological aspects. These three aspects shall be accommodated well in a regional regulation. But in reality many regional regulations were nullified by the Minister of Home Affair and/or MA/Supreme Court (Mahkamah Agung) because the regional regulation legislators have less attention to these three aspects. This condition shows that the regional regulation legislators still have less attention to the philosophical aspects. This study aims to determine the importance of philosophical aspects in creating regional regulations that can help the implementation of regional autonomy to run well. This study applies a normative juridical research method with the method of legislation approach and conceptual philosophical approach related to the object under study.
\end{abstract}

Keywords: Regional Regulation, Legal Content, Regional Autonomy

\section{Introduction}

In a democracy State, the separation of power becomes an aspect that determines the development of democracy. In Indonesia the separation of power is carried out by a check and balance mechanismbetween the executive, legislative and judicial bodies. In the legislative area, the filling of the political superstructure through elections placing people's representatives in the DPR(People's Representative Council) and DPRD (Regional People's Representative Council) is the success of democracy in accommodating people's political participation. At the regional level both the Province and the regency/city related to the people's representative body, in the context of regional autonomy the role of the DPRD is crucial in absorbing people's aspirations and supporting the performance of the regional government. Meanwhile in the executive area, regional central relations have been redefined with systems and mechanisms shifting from a centralized system to a decentralized system. The implementation of the decentralized system provides thenew perspective about people's sovereignty come into being in real governance at the regional level.

As a consequence of regional autonomy, each region may regulate their respective regional affairs in accordance with the scope of regional autonomy authority regulated in laws or regulations. The scope of regional autonomy authority with regard to various aspects of regional government in accordance with the provisions of the law such as the regional authority to appoint regional employees, the regional autonomy authority to determine the regional budget and revenue regulated in regional regulations and others. 
One aspect of the regional independence relates to the independence to form regional regulations. In accordance with this independence, each autonomous region can create regional regulations to regulate regional affairs. The authority to create regional regulations is an attributive authority originating from Article 18 paragraph (6) of the 1945 Constitution which states that the Regional Government reserves the right to establis h regional regulations and other regulations to implement autonomy and co-administration tasks. Therefore, a regional regulation established by a regional representative body together with a regional head in a regional region is a consequence of regionalautonomy that cannot be interfered with by the central government. The legislative function in the regions carried out by the DPRD is certainly in line with the regionalhead in order to advance the region. With the DPRD great authority, the regulations created may possibly develop the region and/or the opposite.

Relating to the legislative function of the DPRD in creating regional regulation as a general-abstract legal principle, it cannot be separated from the provisions of Article 7 paragraph (1) of Law No.12 of 2011 concerning the Establishment of Legis lation, where legislation is known to consist of a). 1945 Constitution, b). MPR (People's Consultative Assembly) Decree, c). UU (Law) / Perpu (Government Regulation in Lieu of Law), d). Government Regulations, e). Provincial Regulations andf). Regency/City Regulations. Later, the Law on the Establishment of Legis lation as amended by Law No. 15 of 2019 concerning Amendment of Law No. 12 of 2011 concerning Establishment of Legis lation which in this study became one of the problems related to the position of the Regional Regulation and its relations hip to the philosophical as pects of the legal content of the Regional Regulation its elf.

The formation of laws is carried out by taking into account various factors such as the development of society, the philosophy of the nation (state), the purpose of the state, environmental conditions, culture and others. The regional representative body or institution carries out or perform the regional regulation formation by discussing the draft regional regulation together with the regional head. In discussing the draft regional regulation, the regional representative body or institution may approve or dis approve the draft regional regulation. In addition, regional people's representative bodies or ins titutions may als o submit proposals for regional regulations and develop programs of regional regulations formation.

Article 14 of Law Number 12 of 2011 has clearly provided directions for legal content that must be stated in the Regional Regulation. These provisions can alsobe regarded at the same time as boundaries that must be considered by the DPRD and Regional Heads in the formation of Regional Regulations. The directions and restrictions provided by the provisions in Article 14 of Law Number 12 of 2011 can be considered very helpful to the legislators in the regional level, in this case the DPRD and the Regional Head. In accordance with the provisions of Article 14 of Law Number 12 of 2011, there are 3 (three) matters that must be considered and at the same time be the guideline for the institutions forming the Regional Regulation namely that the legal contents of the Regional Regulation must consider:

1. Regional Regulations are formed in the context of carrying out regional auton omy and co-administration tasks,

2. Regional Regulation serves to accommodate the specialconditions of the region and

3. Regional Regulation is a further elaboration of higher Legislation.

Article 14 of Law Number 12 of 2011 clearly provides directions for legal content that must be stated in the Regional Regulation. These provisions can also be regarded at the same time as boundaries that must be considered by the DPRD and Regional Heads in the formation of Regional Regulations. 
However, in carrying out the function of creating legislation at the regional level $($ Perda $)$ it still holds weaknesses related to the legal content of the Regional Regulation. Although there are guidelines for the formation of regional regulations, not every region is able to make a good regional regulation by following these provisions perfectly. As the result, there are many regulations that were nullified both by the Ministry of Home Affairs and by the Supreme Court. One of the reasons of regional regulations being nullified is because they are not appropriate and or do notadequately contain philosophical, juridical or sociological as pects . This philos ophical aspect that becomes the main consideration for the reasons for the regional regulations formation, should be in accordance with the views of life, conscience and legal ideals that contain virtues originated from the philos ophy of the Indonesian nation namely Pancasila and the Preamble to the 1945 Constitution.

Revocation of provincial, regency and municipal Regional Regulation reflects a form of legal problems in the context of the formation of laws or regulations (rechtsvorming). The phenomenon of nullifying the RegionalRegulation is not a new phenomenon in the practice of state adminis tration in Indonesia. Since the reformera, laws have provided opportunities for "considerable freedom" for provincial, regency and city governments to administer and manage regional affairs by forming regional regulations in accordance with the characteris tics of their respective regions. However, this "considerable freedom" is accompanied by the practice of nullification regional regulations which is increasingly occurred.

Regional Regulations that are not in accordance with the provisions of Article 14 of Law Number 12 of 2011 as stated above can be requested to be tested in the Supreme Court. If the Supreme Court considers that the Regional Regulation contradicts the higher legis lation, the Regional Regulation may be nullified by the Supreme Court. However, due to the hard and long process of testing regional regulation in the Supreme Court, the Ministry of Home Affairs through the authority of executive review may cancel problematic regional regulations. The Ministry of Home Affairs has nullified thousands of Regional Regulations which are considered problematic and hampered investment. Bas ed on official data from the Ministry of Home Affairs, up to 2016 there have been around 3,143 regional regulations nullified. Thous ands of regional regulations that were nullified were considered to hamper reg ional economic growth, extend bureaucratic path, inhibit licensing and investment processes, inhibit ease of doing business, and contradict higher laws and regulations [1]. The Constitutional Court (MK-Mahkamah Konstitusi) confirmed after the is suance of the Constitutional Court's decree No. 137/PUU-XIII/2015 which provides an interpretation of Article 251 paragraph (2), paragraph (3), paragraph (4) and paragraph (8) of Law No. 23 of 2014 concerning Regional Government, the Minister of Home Affairs may still conduct executive review (nullify) the Provincial Regulation. Because, the Constitutional Court only removed the authority of the Minister of Home Affairs to nullify the Regency/City Regulation. According to the Constitutional Court's decree, the nullification of the Regency/City Regulation can only be reached through a judicial review to the Supreme Court (MA)) [2].

The existence of a Constitutional Court decree that emphasized that the Minis try of Home Affairs was not authorized to nullify Regency/City Regulations provides little hope that regional autonomy is still possible. However, the potential for nullification of Regional Regulation through Judicial Review in the Supreme Court in spite of the long process, will still hamper the implementation of regional autonomy at the regency/city level. The regional government's concern over thenullification of the regional regulation can be understood as a symptomof the inconsis tency of regional authority in managing its own affairs. Therefore, it is important to examine why the philosophical as pects of the regional regulation becomes important in creating the regional regulation? 


\section{Purpose}

This study aims to learn the importance of philosophical aspect in legal content of Regional Regulation and to increase optimization of regional autonomy through the rules. Therefore, it could be guidance for legis lator in creating good Regional Regulation that can be us eful for the people.

\section{Method}

This study uses the normative juridical research method which is conducted to test the research object that is examined with the rule of law and or norms of positive law, which are contained in legislation. In addition to using the legis lation approach, this study also uses a philos ophical approach to see the abstraction of values to be sought from the object under study.

\section{Result and Discussion}

In definition of the Legal State/Rule of Law contains the objective that the State be established to guarantee social order, in general the social order is based on popular sovereignty. According to A.VDicey there are three elements of the Rule of Law namely the Supremacy of law, equality before the law and the constitution based on individual rights. In line with the elements of the Rule of Law Gustav Radbruch explained that there are three functions of the Rule of Law, namely realizing legal certainty, justice and purposiveness [3]. In order to realize the functions of the Rule of Law, arrangements are made regarding the authorities, duties and functions of the government based on the provisions of the law.

Philos ophically, the legal content of regional regulation is the substance to be regulated in regional regulation, the clarity of the purposes and objectives to be achieved, reflected in the series of preamble of the Regional Regulation and its body consisting of Articles. The philosophical, sociological and juridical aspects of regional regulation are seen in the conformity of the legal content principles stipulated in Law No. 32 of 2004. The importance of the legalcontent is in accordance with the principles of the legal content stipulated in the legislation one of which is fulfilling the principles of the Rule of Law. According to Julius Stahlthere are four elements of a formal legal state, namely: 1). Protection of human rights 2). Separation of power; 3). Government based on law; and 4). An independent state judicial adminis tration [4].

Therefore, to underlie government based on law, it must be formed with full consideration of the achievement of legalobjectives in the society. However, it is worth remembering that the Legal State in Indonesia is the Pancasila Legal State/Rule of Law which distinguishes it from the Rule of Law in general. Notonagoro stated that Pancasila is a legal ideal because of its position as thestatefundamental norms (staatfundamentalnorm) which has the power as grundnorm. As a legal ideal, Pancasila is the guide for all national legal products [5]. W ith these guidelines from Pancasila, all legal products of laws and regulations are dedicated to achieving the goal of the State of Indonesia, namely creating a just and prosperous society.

Azhari stated that the Indonesian nation did not choose the western concept (rechstaat) or the Anglo Saxon concept(rule of law), but the concept itself. The legal juridical concept of the rule of law according to the Indonesian nation or the main elements that characterize the 
Indonesian rule of law, namely: [6] 1). Law based on Pancasila, 2). People's Sovereignty, 3). Government based on the constitutional system, 4). Equality in law and government, 5). Independent judicial power, 6). Law legis lator is President together with the DPR, 7). MPR system. Furthermore Azhari looks at the modified elements in accordance with the ideals of the Pancasila state and naming (formulation) which is typical of Indonesia "state based on law", this shows that Indonesia created its own concept of the rule of law based on the ideals of the Pancasila state, but it was not out of universal concepts. So, what is universal is the rule of law that is unique to Indonesia namely state based on law.

To discern which category of rule of law classified as "state based on law", it must be discovered in "what is the purpose of the Republic of Indonesia (state based on law). This is discovered in the Preamble to the 1945 Constitution the fourth paragraph, namely, to protect the whole people of Indonesia and the entire homeland of Indonesia; to advance general prosperity; to develop the nation's intellectual life; to contribute to the implementation of world order based on freedom, lasting peace and social justice. From this guide it can be concluded that the purpose of the state is to create a just and prosperous society, in other words a pros perous society, because the word just does not refer solely to the material, but is closer to (prioritizing) s piritual. Thus the statebased on law can be categorized into a welfare state (verzogingstaat), namely a material pros perous and spiritual prosperous country [7].

Similarly, in the Formation of regional regulation orientating to the enactment of legal objectives in the society, surely the concept of welfare Rule of Law for all the people of Indonesia will be increasingly experienced the benefits.

In organizing the welfare of the people as a state goal cannot be separated from the foundation of the state, namely the constitution. According to Sri Soemantri that from the beginning, the Indonesian state had a concept of a welfare state. This is implied in the fourth paragraph of the Preamble to the 1945 Constitution as follows:

1. Protect the whole people of Indonesia and the entire homeland;

2. Advance general prosperity;

3. Develop the nation's intellectual life;

4. Contribute to the implementation of world order based on freedom, las ting peace and social justice.

By Padmo Wahyono, the four purposes of the state were named elements of a just and prosperous society based on Pancasila dynamically and not utopian terminal (terminal utopistis). If we examine the Indonesian rule of law based on Pancasila furthermore and thoroughly, then a general explanation of the state governance systemcan be used as a basis. In a general explanation it is stated that:

1. The Indonesian state is based on law (rechstaat), not merely based on power (machstaat);

2. Government based on a constitutional system(basic law) is not absolutis m(unlimited power). [8]

The implementation of the ideals of the constitution is realized technically operational through the formation of legislation. The principles of forming legis lation are a guideline in the formation of good legis lation. According to Philipus M. Hadjon, the formation of legislation must be based on the principles of establishing good legislation (algemene beginselen van behoorlijke regelgeving ) [9]. 
The principle of the formation of legislation in addition to as explained by experts is also outlined in positive law in force in Indonesia. This is currently regulated in Law Number 12 of 2011 concerning Establishment of Legislation. Article 5 of Law Number 12 Year 2011 concerning Establishment of Legis lation states: In es tablishing legislation, it must be based on the principle of establishing good legislation, which includes:

a) Clarity of objectives;

b) Appropriate legislator institution or authority;

c) Conformity between types, hierarchy, and legal content;

d) Enforceable;

e) Us ability and efficacy;

f) Clarity of formulation; and

g) Transparency.

In the explanation of the Law mentioned above, Principle of Conformity between types, hierarchy, and legal content is that in the formation of legis lation must thoroughly consider the appropriate legal content in accordance with the type, hierarchy of legislation. This also applies in the formation of Provincial and Regency/City Regulations. Likewise, the principles contained in a regional regulation shall be the same as the higher legis lation. In addition, the validity of a regional regulation must also contain philos ophical, juridical and sociological aspects so that it is enforceable in society.

Specifically with regard to the philosophical foundation in the Regional Regulation, it guides policy makers to reflect the goals of the Indonesian nation. Technically, the embodiment of the welfare state law is derived through the democratic regional regulation establishment. A good regional regulation philosophically can be reflected in the democratic policy making process of the DPRD. If the establishment of regional regulation is made with the orientation of the enactment of legal objectives in society, surely the concept of a welfare Rule of Law for all the people of Indonesia will be increasingly experienced the benefits. Governmental adminis tration in Indonesia that adheres to decentralization has a system and mechanism of regional governments administration that support national ideals while accommodating the needs of each region in accordance with their respective characteris tics. At present decentralized regional government uses the broad autonomy system. Based on broad autonomy authority, the regional government is expected to be able to utilize local wis dom, local potential, innovation, competitiveness and regional creativity to be able to achieve regional goals namely general welfare at the local (regional) level which in turn will surely support the achievement of national goals as a whole that is as well the general welfare or the welfare of all the people of Indonesia. In other words, the objective of implementation at the central (national) and regional government level is the same, namely public welfare. However, the methods adopted by the central government and regional governments are different. The central government takes care of and organizes welfare in general but the regional government takes care of public welfare at the regional level. The scope of affairs of centralgovernment administration is clearly broader than the scope of affairs of managing public welfare by regional governments.

There are various kinds of regional Government Affairs that must be related to basic service affairs. Mandatory government affairs relating to basic services are regulated in Article 12 paragraph (1) of Law Number 23 of 2014 as follows "Mandatory Government Affairs relating to Basic Services as referred to in Article 11 paragraph (2) shall include (1) 
education, (2) health, (3) public works and s patial planning, (4) public housing and residential areas, (5) peace, public order, and society protection and (6) social. With the mention of the types of mandatory government affairs of basic nature as stated above, regional governments can increasingly focus on the implementation of basic service affairs mentioned above.

In addition to mandatory government affairs of basic service nature, there are types of government affairs that must be held by regional governments. However, these mandatory government affairs are not related to basic service matters. Mandatory government affairs held by regional governments relating to non-basic services are regulated in Article 12 paragraph (2) of Law Number 23 of 2014 which regulates as follows:

"Mandatory Government Affairs that are not related to the Bas ic Services as referred to in Article 11 paragraph (2) shall include (1) workforce, (2) women's empowerment and children protection, (3) food, (4) land, (5) environment, (6) population administration and civil registration, (7) community and village empowerment, (8) population control and family planning, (9) transportation, (10) communication and informatics, (11) cooperatives, small and medium enterprises, (12) capital investment, (13) youth and sports, (14) statistics, (15) coding, (16) culture, (17) library and (18) archiving."

Other matters for regional government are optional government affairs as referred to in Article 11 paragraph (1) of Law Number 23 of 2014. If viewed from the order of priority scales, optional government affairs clearly do not have the same nature with the same urgency as mandatory government affairs discussed above. The urgency of optional government affairs occupies a lower position than mandatory governmental affairs. Yus nanti Has yimzoem et al. expresses opinions that describe the characteristics of optional government affairs as provincial government affairs that actually exist and have the potential to improve people's welfare in accordance with the conditions [10].

The type of optional government affairs is regulated in Article 12 paragraph (3) of Law Number 23 Year 2014 which determines as follows "Optional government affairs referred to in Article 11 paragraph (1) includes (1) marine and fisheries, (2) tourism, (3) agriculture, (4) forestry, (5) energy and mineral resources, (6) trade, (7) industrial and (8) transmigration." The type of optional government affairs above are important, but according to the legis lators, optional government affairs do not have the same urgency as mandatory government affairs . Therefore, the term used is optional government affairs. Regional governments have the freedom to choose whether or not to carry out these optional government affairs.

Related to the meaning of broad autonomy does not mean that regional governments have unlimited authority. Regional regulations made by the regional government can be nullified at any time by the Supreme Court (despite the length of the process) and or the Ministry of Home Affairs. So that the legis lative function of the DPRD, both provincial and especially Regency/City, is still bound by the Ministry of Home Affairs' authority to conduct evaluation in terms of co-adminis tration tasks. Even though the Minister of Home Affairs can no longer nullify the Regency/City Regulation (executive review) based on the Constitutional Court's decree. However, the control of the governor and the Minister of Home Affairs as representatives of the central government can still be applied through an evaluation of the Regency /City Draft Regulation (executive preview) [11].

In the event of a nullification of a Regional Regulation, the writer can interpret that the DPRD has a heavier burden and responsibility when compared to the Regional Head related to the nullification of the Regional Regulation. This is because the DPRD has the function and authority as wellas the main task in forming a Regional Regulation rather than the Regional 
Head. Nullification of a Regional Regulation can beregarded that the functions, authority and legislative duties of the DPRD as a regional people's representative institution are not going well. DPRD is considered to fail or be unable to capture and absorb the aspirations of the regional people and unable to form Regional Regulations that are not in conflict with higher legislations. Mean while, the Regional Head who participated in approving the is suance of the Regional Regulation also suffered a loss because he could not administer the government in his region with a definite legal basis in regulating a particular matter needed.

This phenomenon has shown that the making of Regional Regulations based on the needs of decentralization in regional autonomy has shifted to become a political commodity of the government. The meaning of decentralization given by the government as a means to realize people's welfare at the regional level is now being questioned. If the region has already been given the authority to create a Regional Regulation, surely philosophically it would be formed to accommodate the different people's aspirations in each region. When comparing with the history of centralization of power, the regulation of regional government affairs is based on the will of the central government, so that it is not suitable to be applied in some regions because the different characteristics of each region have been ignored.

After the amendment of the 1945 Constitution which emphasized the adoption of a decentralized system, it shifted the paradigm of centralization of power and placed people's sovereignty in realterms from the bottom through regional autonomy. In the context of the development of the Rule of Law, people's sovereignty is in the social sub-system that is in mutualattraction with other sub-systems in society. TalcotParson said that the law is placed to maintain the pattern of cultural values which are guidelines for individual behavior. Pars on also sees that law in the social sub-system of law functions to integrate the regulation of individual activities to meet their needs and prevent conflicts and other matters that interfere with the smooth social relations and productivity of society [12]. This is where the need for a regional regulation to be drafted as a law governing as pects of community life in regions that require special handling according to the needs and social character of the people.

Through regional regulations made, the regional government regulates the implementation of mandatory affairs related to basic services, mandatory affairs not related to basic services and optional affairs as determined in the regional government law. In the process of making a regional regulation involving the DPRD and regional heads, the governmental affairs in the region are based on the needs of the regional society for certain fields to be addressed such as increased regional income, increased society welfare from regional assets and resources and other fields of affairs that need to be regulated. However, when the regional regulation that has been created is nullified by higher institutions, it has displayed that the law as a social sub-systemis in a vulnerable position because it is heavily influenced by other social sub-systems such as politics. The law of determinants towards politics is a social fact that is the reason many of the regionalregulations have been nullified.

Even though under the pretext of synchronizing and harmonizing the legis lations, the aspects of people's sovereignty in the regions should stillbe respected as long as they do not conflict with Pancasila and the 1945 Constitution as well as the principles of establishing a good regional regulation. Philosophical as pects in the legal content of regional regulations to be regulated is the key to the success of the enactment of a law, howeverthe enactment of law in society that is inseparable from the influence of the structure and culture of government administrators is notnecessarily in line with the substance made. Changes in the regime at the centrallevel certainly also affect the politics of law of legis lation formation nationally. Surely the central government desires for full support fromevery provincial and regency/city area in every government action taken. When there is a Regional Regulation that is considered not 
supporting the achievement of national ideals, the regulation is worthy of being nullified and replacing it with an appropriate regulation. This indicates a shift in the meaning of the formation of regional regulations being made to respond to regional needs because of their different characteristics, to becoming regional regulations that function to support the achievement of government political targets .

When in fact the government discovered that there were problematic regional regulations, a review of these regional regulations shall be carried out instead of being immediately nullified. The government should havevision about the efficiency and us efulnes s of the legal content of regional regulations made for improving the quality and productivity of the region. Furthermore, in principle, the aspects of people's sovereignty that manifest in the people aspirations in the region should notbe hindered by the executive preview mechanis m of the draft regional regulation. This will hamper and even violate the people's sovereignty and human rights at the regional level when the people aspirations have been blocked. It would be wise to apply executive review when it comes to the is sue of co-adminis tration task from the central government. While outside the authority of the Ministry of Home Affairs over the regions, problematic regional regulations are examined in the Supreme Court.

Therefore it becomes a necessity that in the design and formation of regional regulations must be formulated with appropriate academic and sociological studies. It is the time for the government to is sue regulations regarding the inclusion of academic texts in establishing a Regional Regulation, in order to be able to truly filter philosophically the intention or needs that a Regional Regulation will regulate. The conception of a welfare Rule of Law will be realized if at the regional level as the smallest scope the government is able to implement laws that guide in achieving the goals of the Indonesian people, namely a just and prosperous society.

\section{Conclusion}

Based on the authority obtained fromthe 1945 Constitution and the regional government law, the regional regulation becomes the basis for the implementation of government affairs in regional autonomy. Philos ophical as pects in the legal content of regional regulations are the ess ential necessity of a regional regulation made by the regional government both provincial and regency/city. The need for governance in the regions will be carried out properly if a regional regulation made is able to accommodate the interests and needs of the society according to the region characteristics. Philos ophically, the characteris tics requirement of regional regulations accommodated in regional unique legal content should be respected as a legal product that reflects the people's sovereignty in the region. At the regional level, regional regulation legis lators need to apply academic and sociological studies to map the need for regional governance more thoroughly. It is very necessary to conduct academic literature study on the draft regional regulation that will be made to comply with the provisions of the applicable legis lations.

In connection with the regional regulations that have been made with the interests of synchronization and harmonization of the legislations, a specific study is needed on the nullification of regional regulations in the Law concerning the establishmnet of legislation. Law No.15 of 2019 concerning the establis hment of legis lations does not specifically discuss the problems of the Regional Regulation so there needs to be a revis ion of the provisions. The regulation of the law that provides specific guideline about the Regional Regulation is expected to minimize the weaknesses in the formation of the Regional Regulation so that the Regional Regulation can be applied and beneficial to the society in regional autonomy. 


\section{References}

[1] https://tirto.id/mendagri-tak-lagi-berwenang-batalkan-perda-bermasalah-cqJ4

[2] Hukum online, April 8th, 2017

[3] Maria Farida Indrati, Sony Maulana Sikumbang, Fatriani Achlan Sirait, Muhammad Yahdi Salampessy, Introductory Module for the Law of the Law Faculty UT, 2015, 15

[4] Hotma P. Sibuea, Principles of State Law, Public Policy and The Prinsiples of Good Governance, Jakarta: Erlangga, 2010, 29

[5] Fajlurrahman Jurdi, The State Law Theory, Malang: Setara Press, 2006, 76

[6] Azhari, Indonesian Rule of Law, Juridical Analysis About that Content, Jakarta: UI Press, 1995, 144

[7] Azhari, Indonesian Rule of Law, Juridical Analysis About that Content, Jakarta: UI Press, 1995, 145

[8] Sri Soemantri, Indonesian Constitutional Law, Bandung: Alumni, 1992, 43-44

[9] Yuliandri, Principles for the Establishment of Good Laws and Regulations, Ideas for the Establishment of Sustainable Laws and Regulations, Jakarta: Rajawali Press, 2009, 14

[10] Yusnani Hasyimzoem et al., Local Government Law, Jakarta: Rajawali, 53

[11] Hukum online, April 8th, 2017

[12] Ronny Ronny Hanitijo Soemitro, Social Perspectives in Solving Legal Problems, Semarang: CV. Agung, 1989, 30 